\title{
THE ADAPTATION OF THE CARING NURSE-PATIENT INTERACTION SCALE (CNPI-70)TO POLISH CONDITIONS ON THE BASIS OF NURSING STUDENTS SELF-ASSESSMENT OF THEIR CARING COMPETENCIES
}

\author{
ADAPTACJA SKALI CARING NURSE-PATIENT INTERACTION (CNPI-70) \\ DO WARUNKÓW POLSKICH NA PODSTAWIE BADAŃ SAMOOCENY KOMPETENCJI \\ OPIEKUŃCZYCH STUDENTÓW KIERUNKU PIELĘGNIARSTWO
}

\begin{abstract}
${ }^{1}$ Department of Nursing Theory, Nicolaus Copernicus University in Toruń, Collegium Medicum in Bydgoszcz
${ }^{2}$ Department of Health Promotion, Nicolaus Copernicus University in Torun, Collegium Medicum in Bydgoszcz

${ }^{3}$ Department of Nursing Theory, Nicolaus Copernicus University in Toruń, Collegium Medicum in Bydgoszcz
\end{abstract}

Su m m a r y

The a i m of the study and the undertaken research is to adapt the CNPI-70 tool to Polish conditions and then to use this scale for the evaluation of nursing students competencies.

Material and methods. A CNPI -70 scale survey was conducted among 486 nursing students analyzing their self-assessment of caring competencies at various levels of university.

Results. The reliability of the scale is very high (Cronbach's $\alpha$ is $O, 97$ ), analyzing the 70 questions of the scale it can be concluded that all, except questions no 5 and 21 , have an average or above average correlation with the result of the overall tool. The analysis also indicates that the removal of a single question from the tool does not affect its overall high reliability.

The results of the self-assessment of caring competencies among nursing students show an increase in competence at the successive levels of the university course. The level of competence is also influenced by the experience of part time students.

Conclusions. The Polish version of the CNPI-70 scale, assessing the caring competence of nurses, takes into account the wide range of professional roles of nurses. Research confirms the high reliability of the scale thus recommending its use in research in nursing and education.
Celem pracy i podjętych badań jest adaptacja narzędzia CNPI-70 do warunków polskich i zastosowanie skali do ewaluacji kompetencji studentów kierunku pielęgniarstwo.

Materiał i metoda. Badania skalą CNPI -70 przeprowadzono wśród 486 studentów kierunku pielęgniarstwo analizując samoocenę poczucia kompetencji opiekuńczych na różnym etapie studiów

Wyniki. Rzetelność skali jest bardzo wysoka $(\alpha$ Cronbacha wynosi O,97) Analizując 70 pytań skali można stwierdzić, że wszystkie - z wyjątkiem pytania 5 i 21 - korelują przeciętnie albo ponad przeciętnie $\mathrm{z}$ wynikiem ogólnym narzędzia. Analiza wskazuje również, że usunięcie pojedynczego pytania z narzędzia nie wpłynie na jego ogólną wysoką rzetelność.

Wyniki samooceny kompetencji opiekuńczych wśród studentów pielęgniarska wskazują na wzrost kompetencji na poszczególnych etapach studiów. Na poziom kompetencji ma wpływ również doświadczenie zawodowe studentów studiów niestacjonarnych.

W n i o s ki . Polskojęzyczna skala CNPI-70 do badania kompetencji opiekuńczych pielęgniarek uwzględnia szeroki 
przekrój ról zawodowych pielęgniarki. Przeprowadzone badania potwierdziły wysoką rzetelność skali rekomendując jej stosowanie w badaniach naukowych w pielęgniarstwie i w edukacji.

Key words: self- assessment, nursing students, CNPI-70 scale adaptation

Stowa kluczowe: samoocena kompetencji, studenci pielęgniarstwa, adaptacja skali CNPI-70

\section{INTRODUCTION}

For several years, the training of nurses in Poland has been subjected to a number of reforms to unify the programs and structure of this field of study in accordance with the requirements of the Council of the European Communities. The stages of the introduced changes have been formulated in European Union documents. The first document, signed in 1995 by the Polish Government and ratified in 1996, was the European Agreement concerning the training and education of nurses, (Journal of laws no.83 of July 17 , 1996, item 384) [1]. Under the Directive 2005/36/EC of the European Parliament and of the Council of 7 September 2005 recognition of professional qualifications was regulated. Currently, nurse training takes place at university level, with a specified number of hours, specified duration of the course and different educational standards for each level [2]. These changes coincided with one of the most important reforms in the higher educational system called the Bologna Process. The main idea of the process was to create the European Higher Education Area by the year 2010. The Bologna Declaration implies the need for a number of modifications to improve the quality of education. The main change is the implementation of the European Qualifications Framework (EQF) into educational practice. An important challenge for nursing, in order to follow the delineated innovations, is to prepare competency framework education programs and then to develop and maintain competence and to evaluate this both during the study course as well as among working nurses [3]. The extent of nurses' competencies is still a matter of discussion both in Europe and worldwide [4]. There is a serious problem with the lack of consensus on the definition of the concept of competency, as well as the interpretation of the competence framework for nurses. Another problem is the lack of consistent, reliable and fully intelligible tools used to conduct the evaluation of competence $[5,6,7,8]$.

In 2013, Kajander-Unkuri Satu, et al. reviewed literature concerning the competence of nursing students in Europe. In this analysis 67 competence areas were identified and classified into eight main categories: (1) professional and ethical values and practice, (2) nursing skills and intervention, (3) communication and interpersonal skills, (4) knowledge and cognitive ability, (5) assessment and improvement of the quality of nursing, (6) professional development, (7) leadership, management and teamwork, and (8) research utilisation [9].In many countries work on adapting the CanMEDS competency frameworks, first developed in Canada by RCPSC in 1996, in the field of nursing, is underway. These frameworks have been subjected to numerous verifications. The fundamental competencies of the CanMEDS relate to seven roles: Medical Expert, Communicator, Collaborator, Health Advocate, Manager, Scholar and Professional [10].

With many discussions focused around the competence of medical workers, particularly competence in nursing, one fundamental and inseparable attribute characterizing nursing always surfaces- it is care and compassion. Both scientists and the general public, including patients, indicated this feature as an essential attribute of competent nurses [11].

By introducing the theory of humanistic care Jean Watson [12] notes that nursing is not only a science, which can be separated from care. The author of the theory claims that human caring combines a humanistic, caring approach and the scientific knowledge of nurses. A nurse must not only display the knowledge of proper technical performance but also, in actions related to health care for a patient, be caring and have appropriate interpersonal skills. The importance of care in nursing is also argued in the deliberations and research of Balsdursdottir and Jonsdottir, and Calman [13, 14].

In accordance with the assumptions of Jean Watson's theory and the competencies defined by her as having care and compassion as their basic attributes, an attempt to use the CNPI-70 scale in the selfassessment of competence in nursing students was made.

The Caring Nurse-Patient Interaction Scale was developed by a team of researchers from the University of Montreal. Sylvie Cossette, Chantal Cara, Nicole 
The Adaptation of the Caring Nurse-Patient Interaction scale (CNPI-70) to Polish conditions, on the basis of nursing students...

Ricard and Jacinthe Pepin. Referring to the assumptions of Joan Watson's theory of humanistic care, the research team developed a tool consisting of 10 subscales reflecting the 10 carative factors characterizing a nurse's caring approach. Studies, carried out by the research team, aimed at assessing the psychometric properties of the scale gave satisfactory results[15].Currently, both the French and English versions of CNPI have proven to be successful not only as a means of research but also in both the clinical and educational field. The relevant wording of the leading question allows obtaining an answer concerning e.g. the meaning and importance of various actions associated with care in nursing practice as defined in the items of the individual subscales, or the degree in which the respondents listed these caring actions as being realistic in the clinical setting. It is also possible to obtain information concerning the sense of competence of nurse practitioners or of nursing students at different levels of the course. The scale can also be used to research the expectations, in terms of nurse care, of patients' families and the public [16]. The wide applicability of the scale presented by the authors became the motive to adapt it to Polish conditions.

Work on the adaptation of the scale began in 2011 in the Department of Nursing Theory at Louis Rydygier Medical College in Bydgoszcz, Nicolaus Copernicus University in Toruń. After obtaining the consent of the authors of the original version from the University of Montreal, whose representative is Professor Sylvie Cossette, translation of the tool commenced. In accordance with the requirements the scale was translated by two independent translators. A supervisor, who was familiar with the whole process, watched over the translation of the tool. The translated scales were assessed in terms of clarity of statements by a team of experienced nurses. The vast majority of the statements contained in the scale were understandable and grammatically correct. The Polish version, with minor adjustments, was then re-translated into English, thus undergoing the process of reverse translations, and then compared with the original version. This Polish version passed a pilot study on a group of 30 students to check whether the wording of the scale and of the instructions, as well as the way to respond, and the rules for calculating the results were clear. The final version of the tool has been used to study a group of 486 students in order to check its reliability and discriminative power.

\section{MATERIAL AND METHODS}

The study involved 486 nursing students from the Faculty of Health Sciences of the University of Nicolaus Copernicus. A group of students was deliberately chosen for the study. The group of students, at different levels of the course, made selfassessments. The study was anonymous as it was the results of the entire groups which were being evaluated. The approval of the Dean of the Faculty of Health Sciences and the Bioethics Committee of the Nicolaus Copernicus University in Torun was obtained in order to use the CNPI- 70 scale amongst students.

The CNPI-70 consists of 70 statements that have been assigned to 10 subscales consistent with the carative factors defined by Jean Watson.

Subscale I. Humanism- Formation of a humanisticaltruistic system of values (6 items), II. HopeInstillation of faith-hope (7 items), III. SensibilityCultivation of sensitivity to one's self and to others (6 items),IV. Helping Relationship- Development of a helping-trusting, human caring relationship (7 items), V. Expression of Emotions-Promotion and acceptance of the expression of positive and negative feelings (6 items),VI. Problem-solving- Systematic use of a creative problem-solving caring process (6 items), VII. Teaching- Promotion of transpersonal teachinglearning (9 items),VIII. Environment- Provision for a supportive, protective and/or corrective mental, physical, societal and spiritual environment (7 items), IX. Needs- Assistance with the gratification of human needs (10 items), X. Spirituality- Allowance for existential-phenomenological-spiritual forces (6 items).

\section{RESULTS}

Nursing students at different levels of the course took part in the research. $15.23 \%$ of the respondents were full time, undergraduate students at the end of their first year. 16. $87 \%$ were full time, postgraduate students at the beginning of their first year. $22.43 \%$ were part time, undergraduate students at the beginning of their first year and $17.7 \%$ were at the same level but at the end of their first year (part time, undergraduate students were individuals employed as nurses supplementing their education). $27.78 \%$ were part time, postgraduate students, employed as nurses, at the beginning of their first academic year.

The reliability of each subscale and of the whole CNPI-70 was measured using the most sensitive 
indicator -Cronbach's $\alpha$ which is based on internal consistency in terms of the classical test theory. The reliability analysis indicated a high level of reliability (internal consistency) of the entire measuring tool ( $\alpha=$ 0.97). Subscales II, V-X were characterized as being of high reliability (above 0.8). Subscales III and IV showed a satisfactory level of reliability (above 0.7). Only the level of reliability of subscale I was not satisfactory, but even so it was not low ( $\alpha=0.68$ ). An evaluation of all the questions included in the individual subscales of the tool to determine their discriminatory power (correlation between the items in the test and the result of the scale) and their Cronbach's $\alpha$ index, in the event that they had been removed from the subscale, was carried out. If this ratio was lower than the overall rate for the individual subscale, this meant that the removal of this question may have lowered (worsened) the reliability of the given subscale. In the opposite case the removal of this question was advised in order to increase the overall Cronbach's ó rate.

The analysis showed that all the correlations between each question and the overall result of subscale I were average. Question 1had the highest correlation $(r=0.48)$, and question 5 had the lowest ( $r$ $=0.38$ ). The removal of any of the questions falling within subscale 1 (except question 5) would have reduced the reliability of this scale. Removal of question 5 would not have change the level of reliability of the scale. Scale I did not receive a satisfactory level of reliability. A simulation using a statistical package indicated that, in order to obtain reliability of 0.8 , it was necessary to add 5 questions.

All correlations between each question and the overall result of subscale II were average. Questions 10 and 12 having the strongest correlation $(r=0.64)$, and question 7 the weakest $(r=0.47)$. The removal of any of the questions falling within this subscale (except question7) would result in the decrease of the reliability of this scale. Removal of questions 7 would not change the level of the subscale's reliability. All correlations between each question and the overall result of subscale III were average. Question 18 had the strongest correlation $(r=0.65)$, and question 19 had the weakest $(r=0.45)$. The removal of any of the questions falling within this subscale (except question7) would result in the decrease of the reliability of this scale. The removal of question 19 would not change the level of the subscale's reliability. All questions, except for question 21, had an average correlated with the overall result of subscale IV. Question 21 correlated below average. Question 25 had the strongest correlation $(\mathrm{r}=0.57)$, and as already mentioned question 21 had the weakest $(r=0.27)$. Removing any of the questions within the scope of this scale (except for question 21) would reduce the reliability of the subscale. Removal of questions 21 would increase the reliability of the subscale from 0.71 to 0.75 . This adjustment was therefore advised. All correlations between each question and the overall result of subscale $\mathrm{V}$ were average or above average. Questions 29 and 31having the highest correlation ( $\mathrm{r}=$ 0.72), and question 28 the lowest $(r=0.53)$. Removing any of the questions falling within this subscale (except question 28) would result in the decrease of the reliability of this subscale. Removing question 28 would not change the level of reliability of the scale.

All correlations between each question and the overall result of subscale VI were average or above average. Question. 36 had the highest correlation ( $\mathrm{r}=$ $0.77)$, and question 38 the lowest $(r=0.62)$. Removing any of the questions falling within this subscale would result in a decrease in the reliability of the subscale. All correlations between each question and the overall result of subscale VII were average or above average. Question. 46 had the highest correlation ( $r=0.73)$, and question 43 the lowest $(r=0.41)$. Removing any of the questions falling within this subscale (except question 43) would result in a decrease in the reliability of the subscale. Removing question 43 would not change the level of reliability of this subscale.

All correlations between each question and the overall result of subscales VIII were average or above average. Question. 53 had the highest correlation $(r=0.66)$, and question 48 the lowest $(r=0.48)$. Removing any of the questions falling within this subscale would result in the decrease of its reliability.

All correlations between each question and the overall result of subscale IX were average or above average. Question. 63 had the highest correlation ( $\mathrm{r}=$ $0.75)$, and question 55 the lowest $(r=0.47)$. Removing any of the questions falling within this subscale (except question55) would result in the decrease of reliability of this scale. Removing question 55 would not change the level of reliability of the scale.

All correlations between each question and the overall result of subscale $\mathrm{X}$ were average or above average. Question. 67 had the highest correlation ( $\mathrm{r}=$ $0.85)$, and question 65 the lowest $(r=0.62)$. Removing any of the questions falling within this subscale (except 
question65) would result in the decrease of reliability of this scale. Removing question 65 would not change the level of reliability of the scale.

By analyzing the questions in the CNPI -70 scale it can be stated that all (except for question 5 and 21) have an average or above-average correlation with the overall result of the test. Question 5 and 21 correlate below average. The strongest association was observed in the case of question $67(\mathrm{r}=0.72)$ and the lowest in the case of, already mentioned, questions $5(\mathrm{r}=0.26)$ and $21(r=0.24)$. The analysis shows that the removal of a single question from the entire test will not affect its overall, high reliability.

The self-assessment of competencies of nursing students on the basis of the CNPI- 70 scale.

A hypothetical assumption that an increase in competence occurs throughout the successive years and successive levels of the university course, was made. It was also believed that the development of competence is affected by both personal traits and professional experience and that levels of certain competences increase only during the II level of studies.

The students participating in the research were divided into five groups according to their level and mode of study. Group 1 consisted of full-time, undergraduate students at the end of their first year, group 2 full time, postgraduate students at the beginning of their first year, group 3 part time, undergraduate students at the beginning of their first year, group 4 part time students supplementing their studies and group 5 part time, postgraduate students at the beginning of their first year.

The students completed the questionnaire referring to individual statements in the subsequent subscales assessing their competence, on a scale of 1-5, in the given area where 1 means not at all - or lack of competence, 2 - a little, 3- moderately, 4-a lot, 5extremely. The results of the averages in each group and subscale are presented in table I.

The original plan was to use the ANOVA to verify the hypothesis concerning the increase of competence in successive years and levels of study. Yet due to the failure to meet the assumptions of normal distribution of the dependent variable in each of the compared groups, the non-parametric Kruskal-Wallis test was used instead. The analysis showed that the study groups differed in all subscales of the test as well as in its overall result. Because the test is sensitive to at least one difference the post-hoc analysis was applied in order to locate all of them. It was observed that in subscale I - Humanism- group 4 peaked and differed significantly from the other groups. Group 1 and group 3 obtained the lowest level in this subscale and differed significantly from groups 4 and 5. Groups 2 and 5 achieved an average score.

Table I. Juxtaposition (for each of the five study groups of nursing students) of the arithmetic mean (M) and standard deviation $(S D)$ of the result in the individual subscales from I to $X$, and of the whole scale

Tabela I. Zestawienie (dla każdej z pięciu badanych grup studentów pielegniarstwa) średniej arytmetycznej (M) $i$ odchylenia standardowego (SD) uzyskanego wyniku w poszczególnych subskalach od I do X $i$ w catej skali

\begin{tabular}{|c|c|c|c|c|c|c|c|c|c|c|}
\hline \multirow{2}{*}{ Subscale } & \multicolumn{2}{|c|}{ group 1 } & \multicolumn{2}{|c|}{ group 2 } & \multicolumn{2}{c|}{ group 3 } & \multicolumn{2}{c|}{ group 4 } & \multicolumn{2}{c|}{ group 5 } \\
\cline { 2 - 11 } & M & SD & M & SD & M & SD & M & SD & M & SD \\
\hline $\begin{array}{c}\text { I Humanism } \\
\text { I Humanizm }\end{array}$ & 4.26 & 0.41 & 4.32 & 0.44 & 4.24 & 0.50 & 4.56 & 0.48 & 4.42 & 0.43 \\
\hline $\begin{array}{c}\text { II Hope } \\
\text { II Nadzieja }\end{array}$ & 3.95 & 0.7 & 4.21 & 0.47 & 4.18 & 0.46 & 4.45 & 0.43 & 4.32 & 0.45 \\
\hline $\begin{array}{c}\text { III Sensibility } \\
\text { III Wrażliwość }\end{array}$ & 3.5 & 0.69 & 3.75 & 0.57 & 3.59 & 0.64 & 4.09 & 0.56 & 3.83 & 0.55 \\
\hline $\begin{array}{c}\text { IV Helping } \\
\text { Relationship } \\
\text { IV Relacje } \\
\text { pomocowe }\end{array}$ & 4.19 & 0.45 & 4.38 & 0.44 & 4.06 & 0.45 & 4.47 & 0.48 & 4.25 & 0.43 \\
\hline $\begin{array}{c}\text { V Expression of } \\
\text { Emotions } \\
\text { V Wyrażanie } \\
\text { emocji }\end{array}$ & 3.48 & 0.7 & 3.91 & 0.64 & 3.95 & 0.59 & 4.26 & 0.55 & 3.93 & 0.53 \\
\hline $\begin{array}{c}\text { VI Problem- } \\
\text { solving } \\
\text { VI Rozwią- } \\
\text { zywanie } \\
\text { problemów }\end{array}$ & 3.42 & 0.72 & 3.69 & 0.66 & 3.78 & 0.59 & 4.18 & 0.57 & 3.88 & 0.58 \\
\hline $\begin{array}{c}\text { VII Teaching } \\
\text { VII Nauka }\end{array}$ & 3.62 & 0.77 & 4.20 & 0.56 & 4.12 & 0.46 & 4.47 & 0.47 & 4.29 & 0.49 \\
\hline $\begin{array}{c}\text { VIII Environment } \\
\text { VIII Środowisko }\end{array}$ & 4.19 & 0.58 & 4.58 & 0.46 & 4.48 & 0.46 & 4.67 & 0.38 & 4.51 & 0.45 \\
\hline $\begin{array}{c}\text { IX Needs } \\
\text { IX Potrzeby }\end{array}$ & 3.8 & 0.68 & 4.30 & 0.45 & 4.52 & 0.41 & 4.76 & 0.34 & 4.59 & 0.35 \\
\hline $\begin{array}{c}\text { X Spirituality } \\
\text { X Duchowość }\end{array}$ & 3.42 & 0.83 & 3.70 & 0.79 & 3.90 & 0.65 & 4.34 & 0.57 & 4.08 & 0.58 \\
\hline \begin{tabular}{c} 
Total \\
\hline
\end{tabular} & $\mathbf{2 6 4 . 5 2}$ & $\mathbf{3 4 . 1 4}$ & $\mathbf{2 8 8 . 4 7}$ & $\mathbf{2 9 . 3 0}$ & $\mathbf{2 8 6 . 8 0}$ & $\mathbf{2 6 . 6 7}$ & $\mathbf{3 0 9 . 2 8}$ & $\mathbf{2 8 . 8 0}$ & $\mathbf{2 9 6 . 3 9}$ & $\mathbf{2 5 . 8 2}$ \\
\hline
\end{tabular}

In subscale II - Hope - group 4 peaked and differed significantly from all other groups except group 5. Group 1obtained the lowest level in subscale II and differed significantly from all other groups. In subscale III Sensibility - group 4 peaked and differed significantly from the other groups. Group 1, once again, obtained the lowest level in this subscale. In subscale IV - Helping Relationship- group 4 peaked and differed significantly from all other groups except group 2. Group 3 obtained the lowest level in subscale IV and differed significantly from all other groups. In subscale $\mathrm{V}$ Expression of Emotions- group 4 peaked and differed significantly from all the other groups. Group 1 obtained the lowest level in subscale $\mathrm{V}$ and differed significantly from all the other groups. In subscale VI - Problem-solving- group 4 peaked and differed significantly from all the other groups. Group 
1 obtained the lowest level in subscale VI and differed significantly from all the other groups. In subscale VII - Teaching - group 4 peaked and differed significantly from the other groups. Group 1 obtained the lowest level in subscale VII and differed significantly from all other groups. In subscale VIII - Environment - Group 4 peaked and differed significantly from all the other groups except group 2. Group 1 obtained the lowest level in this subscale and differed significantly from all other groups. In subscale IX - Needs - all groups differed from each other except for groups 3 and 5. Group 4 peaked in this subscale and differed significantly from the other groups. Group 1 obtained the lowest level in subscale IX and differed significantly from all other groups. In subscale X Spirituality - all groups differ from each other. Group 4 obtained the highest level in this subscale and group 1 obtained the lowest level.

The post-hoc analysis which was carried out on the entire CNPI-70 scale revealed that all the groups were different from each other except for groups 2, fulltime, postgraduate students at the beginning of their course, and 3 represented by part-time, undergraduate students at the beginning of their course and working in the profession. Group 4, part-time, undergraduate students completing their studies and working in the profession, obtained the highest level of competence throughout the test, and differed significantly from the other groups. Group 1, full-time, undergraduate students at the end of their first year, had the lowest general result and differed significantly from all the other groups.

A further analysis set out to show the difference in competence of full-time and part-time students. The above hypothesis was verified by the Mann-Whitney U test, due to the fact that the distribution of results in the compared groups was not compatible with normal distribution.

The analysis showed that full-time students rate their competence significantly lower in all the scales (except subscale IV) than part-time students. The questions in subscale IV, which showed no significant differences between the two groups, relate to competence in creating a relationship with the patient based on the help, trust and human caring.

The next hypothesis about the difference in the level of competence in undergraduate and postgraduate students was verified using the Mann-Whitney U test, due to the fact that the distribution of results in the compared groups was not compatible with normal distribution.

The analysis showed that undergraduate students rate their competence in subscale VII significantly lower than postgraduate students. The students did not differ significantly in the other scales. The questions in subscale VII relate to competence in the promotion of transpersonal teaching and learning (Fig. 1).

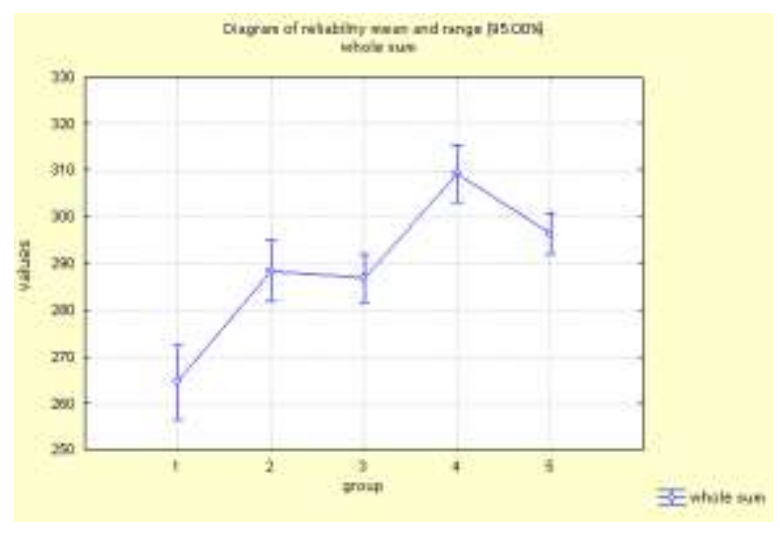

Fig. 1. The increase in competencies in the successive levels of the university course

Ryc. 1. Wzrost kompetencji w kolejnych etapach studiów

\section{DISCUSSION}

The key to professionalism is education based on competency, which has to be consistently reviewed and evaluated. Research indicates that the increase in competence occurs along with the completion of the successive stages of education. First year full-time, undergraduate students evaluated their competence at the lowest levels in all subscales of the tool and their results differ significantly from all the other groups. Students in group 4, represented by individuals who have been working in the profession for some time and who had obtained a nursing degree as a result of completing, in majority, a five year medical school course evaluated their competence at the highest levels. These individuals had decided to supplement their education in accordance with the new standards and, in doing so, obtain a bachelor's degree in nursing. During the research they were at the end of the first level of the course. Both the characteristics of this group as well as the high self-assessment of competence confirm the conclusions of Taborii-Khomerin et al. They believe that motivation is crucial for the development of competency in nurses. External expectations like employer and personal expectations can be motivating factors. The researchers, mentioned 
above, defined the personal traits that are necessary for the development of competence. They mentioned, among others, a willingness to expand knowledge, curiosity, and engagement in activities that can enhance professional skills [17].

There are significant differences in the results of the self-assessments between groups 1,4 , and 5 in the whole CNPI-70 tool, whereas there were no statistically significant differences in the selfassessment of competence between groups 2 and 3 . Group 2 was represented by full-time, postgraduate students at the beginning of their first year. Group 3 was represented by individuals with experience in nursing at the beginning of their part-time, undergraduate course. Although the individuals in Group 3 were only at the beginning of their studies in the new system of education, they assessed their skills similarly to students who had completed a full-time, undergraduate course and started their postgraduate course. This result somewhat confirms that not only formal education but also professional experience affect the growth of competence. Benner indicates and stresses the importance of experience in the growth of competence believing that theory in itself cannot show and allow one to experience the complexities of actual clinical practice [18]. Tabori-Khomeiran, Kiger, ParasYekta and Ahmadi state that some experiences both direct and those reported by other, more experienced nurses, are essential in the development of competence. According to Watson, the shaping of certain competencies begins in early childhood and continues through life. Their development is influenced by the personality and values of the nurse. Empathy and acceptance of differences are the basic features of a nursing adept.

An analysis of the results of the self-assessment carried out by group I would suggest that they are empathetic and have, to some extent, acquired the foundations of holistic health care and the basis of interpersonal communication during their education. Students at the end of their first year achieved the lowest results in all the subscales; however, a detailed analysis of the differences between groups indicates that in subscale IV - Helping relationship- the lowest results were obtained by group 3 . Helping relationships are primarily associated with the ability to create a relationship with the patient based on help, trust and human caring. This subscale includes statements relating primarily to respecting patient's rights and communication skills such as stating ones name and position, listening, not interrupting, not giving the impression that one does not have time for the patient, not opposing, too strongly, to the views and behavior of the patient.

The current system of education, based on a holistic approach which draws attention to patient subjectivity, is aimed at helping to develop an attitude of acceptance of individuality, create a relationship with the patient and respect their rights. The whole content of the educational program at university indicates and teaches how this should be put into practice. Therefore, it is hoped that this curriculum contributes to the development of positive attitudes. Group 3 is represented by nurses with a baggage of experience gained on the basis of the biomedical model. In fact, they have just started gaining education based on newly identified competencies. These individuals received nursing diplomas and gained experience in the period in which patients were the subjects of medical treatment and their rights were not respected. Another bad experience that shaped the attitudes of this group are the working conditions and the lack of reasonable standards of hiring nursing staff. Very often, while oncall, they have to take care of 20 or more patients. With such a negative set of professional experience it is of no surprise that the self-assessment of these competencies is very low. While analyzing the content of the curriculum these individuals ask themselves how is it possible to be available to everyone, and actively listen, and not perform procedures quickly, how is it possible to perform prior commitments when suddenly other patients are in need of help? Even with a high level of empathy, past and present experiences can influence negative attitudes. In modern practice the professionalism of nurses is portrayed in their ability to establish and maintain relationships not only with the patient but also with the medical team. As early as in 1952 Peplau wrote about the principles and the importance of interpersonal relationships in nursing and about creating an atmosphere of acceptance and trust and a relationship based on partnership with the patient [19]. Calman and Shattell indicate that patients, in assessing the ability of nurses, analyze their experiences of care, as they were perceived and treated by nurses $[14,20]$. Therefore, it is not surprising that CanMEDS mentions the role of communicator in its set of core employee roles.

It takes many years for some competencies to appear as they require confidence, well-established knowledge and belief that what one is doing is 
important. Undergraduate students rated their competence significantly lower in subscale VII teaching- than postgraduate students. The competencies included in this subscale relate to the promotion of transpersonal teaching and learning. These skills relate to assisting patients in identifying their lack of knowledge concerning the disease and treatment, giving information to the patient in an appropriate manner, explaining methods of treatment and care, teaching procedures, providing guidance etc. To do so, it is crucial to possess the ability to use knowledge, previous experience, anticipate different situations, and analyze consequences. Potter et al., have identified these skills as critical thinking. It is due to this that a nurse is responsible and able to predict, respond and adapt to the changes and needs of the patient [21]. Among the seven services mentioned in chapter two article 4.1 of the Nurse Practice Act (Journal of laws No. 174, item 1039), which are required of a nurse, appear those related to health education and health promotion. Research by McCann et al., and Whitehead confirmed that nurses are aware that health promotion is an important part of their work, and that health education has very positive results for the patients [22, 23]. Unfortunately, a large percentage of nursing students and practicing nurses believe that there is a certain barrier associated with, firstly, the lack of sufficient knowledge and a discrepancy between theory and practice and, secondly, with the lack of time. The organizational bodies in which nurses work and study also have an impact on the activities of health education and promotion. It is not rare for them to encounter resistance, disregard for the importance of this role and thus lack of support [24].

It should be assumed that postgraduate studies not only provide nurses with additional professional competencies but also a complete higher education resulting in a change in hierarchy and thus allowing for a wider range of independent decisions. Nagelsmith stated that the increase in the level of competence is accompanied by that of self-esteem and initiative [25].

\section{CONCLUSION}

Competencies are the proven abilities to use knowledge, specific skills and values required of qualified health care professionals. They are shaped and develop over time in the process of education and then during the course of work in the profession, they are subject to continuous updating. For this reason, it is important that they undergo systematic evaluation, which should be consistent and clear to all, as should be the definitions of key competencies. A complete assessment of the competence of nursing students and nurses is comprised of the evaluation of teachers, superiors, co-workers, patients, and self-assessment, the last of which in spite of frequent criticism for its subjectivity is one of the most important and valuable methods used in the evaluation of the learning process $[26,27]$. The CNPI-70 scale, used in the selfassessment of competencies, allows students who are at the beginning of their education to discover the ideas and principles which shape nurse's competencies during the course of education. Furthermore, it allows students to gain supplementary education to conduct retrospections of their own competencies. The scale can also be used by employers, co-workers and patients to assess nursing competencies.

\section{REFERENCES}

1. Kózka M.: Efektywność kształcenia zawodowego na studiach pielęgniarskich pierwszego stopnia w okresie transformacji systemu edukacji. Uniwersyteckie Wydawnictwo Medyczne „Vesalius” Kraków, 2008.

2. Marrow C.: Developing nurse education and practice across the European Union. J Nurs Res, 2006; 11(4): 289-290.

3. Smith S.A.: Nurse competency. A concept analysis. In J Nurs, 2012; 23, (3): 172-185.

4. Yanhua C., Watson R.: A review of clinical competence assessment in nursing. Nurs Educ Today, 2011; 31 (8): 832-836.

5. Fordham A.: Using a competency based approach in nurse education. Nurs Stand, 2005; 19 (52): 41-48.

6. Cowan D.: Norman I., Coopamah V.: Competence in nursing practice: A controversial concept - a focused reviev of literature. Nurs Educ Today, 2005: 25: 355-362.

7. Bradshaw A.: Competence and British nursing: a view from history. J Clin Nurs, 2000; 9 (3): 321 - 329200.

8. Bradshaw A., Merriman C.: Nursing competence 10 years on; Fit for practice and purpose yet? J Clin Nurs, 2008; 17 (10): 1263-1269.

9. Kajander - Unkuri S., Salminen L., Saarikoski M., et al.: Competence areas of nursing students in Europe. Nurs Educ Todey, 2013; 33 (6): 625-632.

10. http://www.royalcollege.ca/portal/page/portal/rc/canmeds /framework

11. Girot E.A.: Assessment of competence in clinical practice review of the literature. Nurs Educ Todey, 1993; 13: 83-90.

12. Watson J.: Nursing: Human science and human care A theory of nursing. National League of Nursing Press. New York 1988. 
13. Balsdursdottir G., Jonsdottir H.: The importance of nurse caring behaviors as perceived by patients receiving care a tan emergency department. 2002; Heart \& Lung: J Crit Care, 31 (1): 67-75.

14. Calman L.: Patients`views of nurses` competence. Nurs Educ Todey, 2006; 26:719-725.

15. Cassette S., Cara C., Ricard N., Pepin J.: Development and psychometric evaluation of a scale to assess patientnurse interactions with a caring worldview. Int $J$ Nurs Stud, 2005; 42: 673-686.

16. Watson J.: Assessing and Measuring Caring in Nursing and Health Sciences, Springer Publishing Company, New York, 2009: $241-250$.

17. Tabari - Khomeiran R., Kiger A., Parsa- Yekta Z., Ahmadi F.: Competence development among nurses: The process of constant interaction. J Contin Educ Nurs, 2007; 38 (5): 211-218.

18. Benner P.: From novice to expert: Excellence and power in clinical nursing practice. Menlo Park, CA: Addison Wesley, 1984.

19. Peplau H.: Interpersonal relations in nursing: A conceptual frame of reference for psychodynamic nursing. ( Originally published in 1952). Springer, New York 1991.

20. Shattell M.: Nurse - patient interaction: A review of the literature. J Clin Nurs, 2014; 13: 714-722.

21. Potter P., Wolf L., Boxerman S., et al.:Understanding the cognitive work of nursing in the acute care environment. J Nurs Adm, 2005; 35 (7-8): 327-335.
22. McCann T.V., Clark E., Rowe K.: Undergraduate nursing students` attitudes towards health promotion. Nurs Health Sci, 2005; 7: 164 -174.

23. Whitehead D.: Health education, behavioural change and social psychology: nursing`s contribution to health promotion? J Adv Nurs, 2001; 34 (6): 822-832.

24. Holt M., Warne T.: The educational and practice tensions in preparing pre- registration nurses to become health promoters: a small scale explorative study. Nurs Educ Pract, 2006; 7 (6): 373-380.

25. Nagelsmith L.: Competence: An evolving concept. J Contin Educ Nurs, 1995; 26 (6): 245-248.

Address for corroespondence:

Mirosława Felsmann

Zakład Teorii Pielęgniarstwa

UMK w Toruniu

Collegium Medicum w Bydgoszczy

ul. Łukasiewicza 1

e- mail: miroslawa.felsmann@cm.umk.pl

Anna Andruszkiewicz

(e-mail: kizpromzdr@cm.umk.pl)

Agata Kosobucka (e-mail: kosobucka@cm.umk.pl)

Received: 17.03.2015

Accepted for publication: 8.06.2015 